Jurnal Keperawatan Padjadjaran

ISSN 2338-5324 (print)

ISSN 2442-7276 (online)

Online di http://jkp.fkep.unpad.ac.id

DOI : $10.24198 / \mathrm{jkp}$

\title{
The Influence of Gong Waning Music Therapy toward Anxiety in Patients with Acute Coronary Syndrome
}

\author{
Ode Irman, Yosefina Nelista, Yosephina Maria Hawa Keytimu \\ Faculty of Health Sciences, Nusa Nipa University, Maumere, Indonesia \\ Corresponding email: irmanlaodeaesa@ymail.com
}

Submitted: 27-11-2019 Accepted: 21-02-2020 Published: 01-04-2020

\begin{abstract}
Anxiety becomes a psychological response when there is an attack and becomes a cause to bad treatment of Acute Coronary Syndrome (ACS) patients. Music therapy interventions to reduce anxiety need to be considered because it has no harmful effects. The study aimed to analyze the influence of gong waning music therapy toward anxiety in patients with ACS in Regional Public Hospital of dr. T.C. Hillers Maumere. The research design was quasi experimental with non-equivalent control group design. The sample was 32 patients divided into 2 groups with 16 patients per group taken by using purposive sampling technique. The intervention was implemented in three days. State Trait Anxiety Inventory (STAI) was used as the instrument of the study. The study used paired t-test, independent sample t-test and repeated anova for data analysis. The study showed that experimental group's trait anxiety and state anxiety were reduced (p 0.000 and 0.001 ). There was a difference on anxiety in experimental and control group ( $\mathrm{p} 0.043$ and 0.049 ). There was a bigger decrease of anxiety level in experimental group and it was statistically significant ( $\mathrm{p} 0.000$ ). The findings proved to support intervention of traditional music therapy to reduce anxiety. Nurses should not only focus on physical problems and ignore anxiety. It is hoped that nurses can use music therapy as a non-pharmacological adjunct therapy to help reduce anxiety of ACS patients.
\end{abstract}

Keywords: ACS, anxiety, music therapy. 
Ode Irman: The Influence of Gong Waning Music Therapy toward Anxiety in Patients with Acute Coronary Syndrome

\section{Introduction}

Acute Coronary Syndrome (ACS) is the emergency condition of Coronary Heart Disease (CHD) and is the most leading cause of death in the world that is increasing annually. Each year, around 1.8 million of Europeans die due to CHD (Townsend et al., 2016; Piironen et al., 2016). It is also reported that there are 7 million deaths in Asia-Pacific annually due to the disease (Ohira et al., 2013; Chan et al., 2016). American Heart Association (AHA) reports that as many as 16.5 million adult Americans suffer from CHD (Benjamin et al., 2018). CHD's prevalence increases in developing countries such as Indonesia, China, India, Iran, Turkey and Africa from 9 millions in 1990 to 19 millions in 2020 (Okrainec et al., 2004; Sanchis et al., 2016). Based on the Basic Health Research of 2013, the heart disease prevalence in Indonesia was $0.5 \%$ and it increased to $1.5 \%$ in 2018 . The highest CHD prevalence $(4.4 \%)$ was in East Nusa Tenggara (Ministry of Health of the Republic of Indonesia, 2018).

Anxiety becomes a psychological response when there is an attack and it is reportedly that more than $86.3 \%$ of ACS patients experience anxiety during their treatment in the hospital (Abu Ruz et al., 2010; Wan-Nor-Asyikeen et al., 2017). Anxiety is caused by chest pain, bad conditions, helplessness and death threat (Meneghetti et al., 2017). Anxiety becomes a risk factor to accelerate cardiac death (Parker et al., 2010; Roest et al., 2014). Roest et al. (2010) explained that $36 \%$ of morbidity and cardiac death are due to anxiety. Additionally, anxiety is related to acute level of the disease and prolonged treatment period and decreased quality of life (Abu Ruz et al., 2010; Nuraeni et al., 2016). Celano et al. (2016) in their meta-analysis reported that anxiety affects 1.2 times in accelerating death risks.

Anxiety can be managed by giving sedation, yet this action does not completely solve the problem, therefore, adjunctive non-pharmacological therapy such as music therapy are needed. The use of music therapy was chosen, because there were no side effects, non-invasive, inexpensive and easy to implement (Stern, 2013; Hole et al., 2015). Systematic reviews of research results have reported that music therapy not only reduces anxiety in heart patients but also in patients with mechanical ventilation and chemotherapy (Trape, 2010; Bradt, 2016). Music therapy is not only able to reduce anxiety but also stabilize physiological functions such as blood pressure and heart rate (Di Nasso et al., 2016). Boccara et al. (2018) in their study mentioned that with music therapy patients who undergoing coronary angioplasty require three times less midazolam.

Music as therapy is music that gives relaxing effect and hemodynamic system stabilization (Supnet et al., 2016). Leininger (1978) stated that the result of treatment would be optimal if adapted to local culture (Busher, 2016; Giger, 2016). Facai et al. (2016) in their study using Chinese traditional music therapy, showed psychological disorders can decrease in the experimental group. Currently, many studies in Indonesia use classical music from Europe to reduce anxiety, but the use of traditional music is still rarely chosen. While in Indonesia, there is a lot of traditional music that needs to be developed as a therapy. One of the traditional music in Sikka District is "Gong Waning". Gong Waning's music is the same as other traditional music in Indonesia, gong waning music gives a calm, peaceful and happy effect. When the patient relaxed it will stimulate the parasympathetic nerves, lower blood pressure and reduce anxiety (Loomba et al., 2012).

An initial study in Regional Public Hospital of dr T.C.Hillers Maumere in June 2018 showed that the nurses did not pay attention to patients' anxiety. The nurses focused more on physical problems and medical therapy, meanwhile anxiety affects to clinical deterioration of the patients. The initial study also showed that 7 out of 10 patients feeling worried, threatened, afraid of illness, often thinking about death and helpless. Based on the problems being discussed in prior, the researcher was interested to conduct a study on the influence of Gong Waning music therapy toward ACS patients'. The study aimed to analize the influence of gong waning music therapy toward anxiety in patients with Acute Coronary Syndrome in Regional Public Hospital of dr. T.C. Hillers Maumere. 
Ode Irman: The Influence of Gong Waning Music Therapy toward Anxiety in Patients with Acute Coronary Syndrome

\section{Method}

This study used quasi experimental with non-equivalent control group design. The population of the study was ACS patients being treated in Intensive Care Unit (ICU) of Regional Public Hospital of dr. T.C. Hillers Maumere in 2019. Purposive sampling was used in the study. Based on the average visit of ACS patients in two months as many as 35 patients. Then the sample size can be calculated by the formula (Dahlan, 2013):

$$
\mathrm{n} 1=\mathrm{n} 2=\left[\frac{(\mathrm{Z} \alpha+\mathrm{Z} \beta) \cdot \mathrm{SD}}{\mathrm{d}}\right]^{2}
$$

Information:

$\mathrm{n}=$ sampel size

$Z \alpha=$ type I error $(\alpha 5 \%=1.96)$

$Z \beta=$ type II error II $(\beta 10 \%=1.28)$

$\mathrm{SD}=$ standard deviations between groups (previous studies)

$\mathrm{d}=$ the minimum difference that is considered significant from the results of previous studies.

Based on the research of Alamsah et al. (2018), the standard deviation was obtained (5.29) and the minimum difference (4.51). Then the sample size needed in this study:

$$
\begin{aligned}
& \mathrm{n} 1=\mathrm{n} 2=\left[\frac{(1.96+1.28) \cdot 5 \cdot 29}{4.51}\right]^{2} \\
& \mathrm{n} 1=\mathrm{n} 2=14.44 . \text { Round to } 14 .
\end{aligned}
$$

To avoid samples that drop out, a correction of $10 \%$ is carried out (Sastroasmoro, 2014). So the sample must be added as much as $10 \%$, so to get the overall sample size can be calculated by the formula: $n^{\prime}=n /(1-f)$ Information:

$\mathrm{n}=$ sample size

$\mathrm{f}=$ drop out

$\mathrm{n}^{\prime}=14 /(1-0.1)$

$n '=16.04$. Rounded up to 16 respondents for each group. The total sample size in this study were 32 respondents.

The inclusive criteria of the samples in the study were: 1) Patients have been diagnosed to suffer from ACS, 2) ACS patients come from Sikka district, 3) Patients were getting standard treatment of ACS, 4) Patients were those who got first attack, 5) Patients could communicate well and were willing to be respondents. The exclusive criterion of the study was patients did not follow the process of the study to completion.

The study took place in ICU of regional public hospital of dr. T.C. Hillers Maumere during May-August 2019. The instrument of the study was State Trait Anxiety Inventory (STAI). This instrument fit the problem of the study because there is no statement of psychological response so that it will not cause mistakes between anxiety response and physical effect of ACS. The validity test results obtained the correlation coefficient (0.526-0.897) and the reliability test results obtained Cronbach Alpha: 0.740. There were 2 parts of STAI: State Anxiety and Trait Anxiety; each contained 20 numbers. Each part was given score ranging from 20 to 80 (Julian, 2011).

Data collection includes: 1) Pre-test. Conducted after an ethics test and research permit are obtained, then introducing themselves to prospective respondents, explaining the purpose of the study and giving informed consent to the respondent to be signed. Keeping the environment calm and maintaining patient privacy by putting up barriers or lowering curtains, then measuring anxiety. 2) Intervention. The intervention was carried out for three days. In the experimental group, the patient was arranged in a comfortable position (lying down), the patient closed his eyes, keeping the environment calm and patient privacy. Patients listen to gong waning music for 30 minutes every morning through headphones/earphones (once a day). Music volume is determined by the respondent (maximum $60 \mathrm{~dB}$ ). In contrast, no music therapy intervention was applied to the control group. 3) Post-test. Post-tests were carried out after the intervention was given to the experimental group. Measurements were also made in the control group

Normality test results showed anxiety data both the experimental group and the control group were normally distributed, then the statistical test used paired t-test. Meanwhile, to know the difference of anxiety 
Ode Irman: The Influence of Gong Waning Music Therapy toward Anxiety in Patients with Acute Coronary Syndrome

between the experimental group and control group, independent sample t-test was used. In addition, repeated anova test was used to compare the average number of anxiety with more than two times measurement. This study has got ethical approval agreement from the research ethics commision of Medical Faculty of Nusa Cendana Univesity of East Nusa Tenggara Timur with number: 22/UN15.16/
KEPK/2019. Based on the results of the ethical decision, the study was only carried out on respondents who were already stable and if in the research process the respondent suddenly experiences deterioration, then the respondent is excluded from the study.

Table 1 Distribution of Demographic Characteristics of Respondents $(n=32)$

\begin{tabular}{|c|c|c|c|c|c|}
\hline \multirow{2}{*}{ Respondent Characteristics } & \multicolumn{2}{|c|}{$\begin{array}{c}\text { Experimental Group } \\
(n=16)\end{array}$} & \multicolumn{2}{|c|}{$\begin{array}{c}\text { Control Group } \\
(n=16)\end{array}$} & \multirow{2}{*}{ P value } \\
\hline & $\mathbf{F}$ & $\%$ & $\mathbf{F}$ & $\%$ & \\
\hline \multicolumn{6}{|l|}{ Age } \\
\hline Mean \pm SD & $59.2 \pm 5.5$ & & $57.6 \pm 5.6$ & & 0.989 \\
\hline \multicolumn{6}{|l|}{ Sex } \\
\hline Male & 11 & 68.8 & 12 & 75 & 0.350 \\
\hline Female & 5 & 31.2 & 4 & 25 & \\
\hline \multicolumn{6}{|l|}{ Education } \\
\hline Primary school & 5 & 31.2 & 4 & 25 & 0.790 \\
\hline Junior high school & 7 & 43.8 & 6 & 37.6 & \\
\hline Senior high school & 3 & 18.8 & 5 & 31.2 & \\
\hline Higher education & 1 & 6.2 & 1 & 6.2 & \\
\hline \multicolumn{6}{|l|}{ Occupation } \\
\hline Housewife & 4 & 25 & 4 & 25 & 0.628 \\
\hline Farmer & 7 & 43.8 & 5 & 31.2 & \\
\hline Civil servants & 2 & 12.5 & 2 & 12.5 & \\
\hline Retired & 1 & 6.2 & 0 & 0 & \\
\hline Fisherman & 1 & 6.2 & 2 & 12.5 & \\
\hline Entrepreneur & 1 & 6.2 & 3 & 18.8 & \\
\hline \multicolumn{6}{|l|}{ Type of ACS } \\
\hline STEMI & 5 & 31.2 & 4 & 25 & 0.903 \\
\hline NSTEMI & 9 & 56.2 & 9 & 56.2 & \\
\hline UAP & 2 & 12.5 & 3 & 18.8 & \\
\hline
\end{tabular}

Table 2 Distribution of Respondents Based on Anxiety ( $n=32)$

\begin{tabular}{|l|c|c|c|c|}
\hline \multirow{2}{*}{ Anxiety } & \multicolumn{2}{|c|}{ Experimental Group (n=16) } & \multicolumn{2}{c|}{ Control Group (n=16) } \\
\cline { 2 - 5 } & Mean & SD & Mean & SD \\
\hline Pre & & & & \\
\hline Trait Anxiety & 43.62 & 6.22 & 38.37 & 6.54 \\
\hline State Anxiety & 45.87 & 6.28 & 40.00 & 7.78 \\
\hline Post & & & & \\
\hline Trait Anxiety & 42.87 & 6.35 & 38.06 & 6.52 \\
\hline State Anxiety & 43.75 & 6.21 & 39.00 & 6.88 \\
\hline
\end{tabular}


Ode Irman: The Influence of Gong Waning Music Therapy toward Anxiety in Patients with Acute Coronary Syndrome

Table 3 Influence of Gong Waning Music Therapy toward Anxiety in Patients with ACS (paired t-rest) $(n=32)$

\begin{tabular}{|l|c|c|c|c|c|c|}
\hline \multirow{2}{*}{ Anxiety } & \multicolumn{3}{|c|}{ Experimental Group (n=16) } & \multicolumn{3}{c|}{ Control Group (n=16) } \\
\cline { 2 - 7 } & Mean & SD & P value & Mean & SD & P value \\
\hline Trait Anxiety & & & & & & \\
\hline Pre & 43.62 & 6.22 & 0.001 & 38.37 & 6.54 & 0.136 \\
\hline Post & 42.87 & 6.35 & & 38.06 & 6.52 & \\
\hline State Anxiety & & & & & & \\
\hline Pre & 45.87 & 6.28 & 0.000 & 40.00 & 7.78 & 0.088 \\
\hline Post & 43.75 & 6.21 & & 39.00 & 6.88 & \\
\hline
\end{tabular}

Table 4 Differences in Anxiety after Intervention between Experimental and Control Group (independent samples t-test) $(n=32)$

\begin{tabular}{|l|c|c|c|c|c|c|c|}
\hline \multirow{2}{*}{ Anxiety } & \multicolumn{2}{|c|}{ Experimental Group (n=16) } & \multicolumn{2}{|c|}{ Control Group (n=16) } & $\begin{array}{c}\text { Mean } \\
\text { Difference }\end{array}$ & $\begin{array}{c}\text { Levene's } \\
\text { Test }\end{array}$ & P value \\
\cline { 2 - 5 } & Mean & SD & Mean & SD & & \\
\hline Trait & 42.87 & 6.35 & 38.06 & 6.52 & 4.81 & 0.758 & 0.043 \\
\hline State & 43.75 & 6.21 & 39.00 & 6.88 & 4.75 & 0.832 & 0.049 \\
\hline
\end{tabular}

Table 5 Comparison of Anxiety Before and After The Administration of Gong Waning Music Therapy (repeated anova) $(n=32)$

\begin{tabular}{|l|c|c|c|c|c|c|c|c|}
\hline Anxiety & $\begin{array}{c}\text { Experimental } \\
\text { Group } \\
(\text { Mean } \pm \text { SD) }\end{array}$ & $\begin{array}{c}\text { Mean } \\
\text { Difference }\end{array}$ & F & P Value & $\begin{array}{c}\text { Control } \\
\text { Group } \\
(\text { Mean } \pm \text { SD) }\end{array}$ & F & $\begin{array}{c}\text { Mean } \\
\text { Difference }\end{array}$ & P value \\
\hline Trait & & & & & & & & \\
\hline Pre & $43.62 \pm 6.22$ & & 12.00 & 0.000 & $38.37 \pm 6.54$ & 1.56 & & 0.211 \\
\hline Post 1 & $43.12 \pm 6.25$ & 0.50 & & & $38.12 \pm 6.34$ & & 0.25 & \\
\hline Post 2 & $42.87 \pm 6.19$ & 0.75 & & & $38.12 \pm 6.56$ & & 0.25 & \\
\hline Post 3 & $42.87 \pm 6.35$ & 0.75 & & & $38.06 \pm 6.52$ & & 0.31 & \\
\hline State & & & & & & & & \\
\hline Pre & $45.87 \pm 6.28$ & & 50.89 & 0.000 & $40.00 \pm 7.78$ & 2.16 & & 0.105 \\
\hline Post 1 & $44.37 \pm 6.24$ & 1.50 & & & $39.75 \pm 7.65$ & & 0.25 & \\
\hline Post 2 & $43.81 \pm 6.15$ & 2.06 & & & $39.81 \pm 7.06$ & & 0.18 & \\
\hline Post 3 & $43.56 \pm 6.15$ & 2.12 & & & $39.00 \pm 6.88$ & & 1.00 & \\
\hline
\end{tabular}

Based on the demographic characteristics of the respondents in table 1 . The highest average age is 59 years old. In addition it was dominated by male, junior high school education, employment as a farmer and type of ACS: NSTEMI. All aspects of characteristics obtains the $p$ value $>0.05$, meaning that there are no differences in characteristics both group.

Based on table 2. The highest average anxiety score in the experimental group and at the post-test all anxiety scores decreased.

Based on table 3, the result of paired t-test showed that the $p$ value of experimental group was $<0.05$ (trait anxiety $=0.001$ and state aniety $=0.000$ ), Ho was rejected while Ha was accepted. Hence, there was an influence of gong waning music therapy to ACS patient's anxiety.

Based on table 4, before the independent samples $t$ test was tested, a homogeneity test (levene's test) was performed as a test requirement. Levene's test results obtained $p$ value on trait anxiety and state anxiety $(0.758$ and 0.832 ), $p$ value $>0.05$, then the data have the same variant (homogeneous). Independent 
Ode Irman: The Influence of Gong Waning Music Therapy toward Anxiety in Patients with Acute Coronary Syndrome

samples $t$ test results obtained $p$ values in trait anxiety and state anxiety (0.043 and 0.049$)$, $\mathrm{p}$ values $<0.05$, so there are differences in anxiety after the intervention between the experimental and control groups.

Based on table 5, after 3 days of intervention the decrease in anxiety was higher in the experimental group The results of repeated anova test showed in the treatment group the $p$ value $(0.000)$ and in the control group the $p$ value $(0.211$ and 0.105$)$, so it can be concluded that there are differences in anxiety in the experimental group and there is no difference in anxiety in the control group.

\section{Discussion}

The study resulted $\mathrm{p}$ value of trait anxiety $=$ 0.001 and state anxiety $=0.000)<0.05$, in which Ho was rejected and Ha was accepted. In other words, there was an influence of gong waning music therapy toward ACS patients' anxiety. Anxiety is the psychological response toward changes of physical condition and becomes a phenomenon that often occurs during treatments in the hospital. Anxiety is also a form of emotion which causes mental strain, and if it is not resolved the depressed emotion can disturb heart system and respiratory system (Thompson, 2009). Increased heart workload and increased oxygen demand can worsen myocardial perfusion. The decrease of myocardial perfusion can cause increased chest pain. According to Musey and Kline (2017), anxiety is closely related to chest pain frequency, impacts the activity intolerance and develops physical limitation. Anxiety also impacts reduce of immunity and increases cortisol's production (Lenze et al., 2011).

Anxiety is a form of unpleasant emotion dominated by fear, worries and uncontrolled discomfort toward threatening condition. There are many ways to reduce ACS patients' anxiety; two of them are through pharmacology and non-pharmacology therapies. The pharmacology therapy is given by sedation, yet this therapy causes many side effects that can worsen physical condition of the patients, such as nausea and vomits, bradycardia, hypotension, digestive disorder, physical activity's degradation, easily tired and delirium. Although there are standard operational procedures and instructions on sedation usage by doctor, patients still significantly experience anxiety (Chlan et al., 2013).

Non-pharmacology intervention such as music therapy can help reduce anxiety and also reduce administration of sedative medicine (Bradley et al., 2015; Yeo et al., 2013). Music can strongly distract attention that can also reduce anxiety. It is because music affects brain work with an effect of hemodynamics stabilization (Loomba et al., 2012). Clinical reports also show that music therapy reduces sedative and analgesic medicine administration (Good, 2008). A study by Berbel et al. (2007) compared the use of diazepam with music therapy and it showed that both diazepam and music therapy were effective in reducing anxiety. Unlike pharmacology therapy, music therapy does not have any side effect. Moreover, some studies show that music therapy can help reduce nausea and vomit (Zhou et al., 2011).

In Indonesia, a research using traditional music was shown on Alamsah et al. (2018) study. They used music from Kacapi Suling "Ayun Ambing" that gave influence to anxiety on patients who were doing hemodyalisis. Yusli and Rachma (2019) in their research also stated that there was an influence of Gamelan Jawa music toward elderly's anxiety level. This study was different from that of Rahman et al. (2017). They used traditional music of hariring kabayan in West Java, but there was no influence of the music toward anxiety. This was because patients focused on the pain they were feeling. A study in Turkey using Turkish music also showed there was no significant difference on anxiety decrease between two groups (Toker \& Kömürcü, 2017).

Based on the study result, the mean difference of trait anxiety was 4.81 , while mean difference of state anxiety was 4.75. The result of levene's test on trait anxiety $(0.758)$ and state anxiety $(0.832)$ was more than $(>) 0.05$, hence the data variant on trait anxiety and state anxiety was same. Additionally, $p$ values in the study were 0.043 and 0.049 , with $p$ value less than 0.05 , so it can be concluded that there was a difference of anxiety level between experimental group 
Ode Irman: The Influence of Gong Waning Music Therapy toward Anxiety in Patients with Acute Coronary Syndrome

and control group. This difference occurred due to the intervention of gong waning music therapy. Music therapy is a comprehensive, systematic and therapeutic management to help reduce anxiety, improve quality of life and fasten recovery (Bruscia, 2014; Aggelopoulou et al., 2017).

According to repeated anova test result, $\mathrm{F}$ value was obtained for both trait anxiety and state anxiety (12.00 and 50.89) with $\mathrm{p}$ value $=0.000$. Thus, it can be inferred that the provision of gong waning music therapy influenced significantly toward ACS patients' anxiety. The control group did not show a significant change on anxiety level $(\mathrm{p}=$ 0.211 and 0.105$)$. This study is similar to a meta-analysis study by Tao et al. (2016) explaining that Chinese traditional music can help reduce anxiety. Nilsson's study (2009), showed a different result in which there was no difference of anxiety level among the groups due to limited choice of music. Hanser (2014) explained that although there were many studies on music therapy with different results, the anxiety level of all traces of patients with heart disease decreased after listening to music.

This study showed that the state anxiety level was higher than trait anxiety level both in experimental group and control group, while trait anxiety in control group tended to settle. According to Leal et al. (2017), the higher the trait anxiety level, the higher state of anxiety level it is. Although during the study patients did not say they were worried, they were susceptible toward various situations making them anxious. Based on Spielberger's statement (2010), he explained that there was a relationship between trait anxiety and state anxiety. The higher the level of trait anxiety, the higher level of state anxiety it is that the patients are experiencing. Level of someone's trait anxiety tends to be settling because trait anxiety refers to his/her characteristics or relatively sedentary trait that directs someone to interpret a condition as threats affected by previous experience. This study is in line with the study conducted by Miličić et al. (2016) showing that there was a higher level of state anxiety than trait anxiety $(p$ 0.001 ). Likewise, the study of Maisyaroh et al. (2015) showed that $46.4 \%$ of respondents had moderate state anxiety originating from mild trait anxiety. Trait anxiety is not directly seen on someone's behavior, but it can be seen from the frequency of state anxiety which conditions can change depending on recent situations.

Based on the findings of the study, it is shown that state anxiety score decreased for 1.50 on the first day of gong waning music therapy. This number is higher than that in control group $(0.25)$. On the second day, the state anxiety level decreased for 2.06. Meanwhile, the score of state anxiety decreased up to 2.12 on the third day. It means that when patients listened to gong waning music for 3 days, their anxiety level decreased for 2.12. Trait anxiety and state anxiety in the control group tend to persist. Anxiety decrease was due to strains of gong waning music that could create relaxing, happy and calming effects. The study is also in agreement with nursing theory from Leininger stating that nursing intervention will be optimal if it is linked to local cultural elements. This study will definitely add to the treasury of scientific studies on the influence of traditional music therapy toward anxiety decrease.

Emphasis on scientific approach has become a key to develop and apply traditional music therapy to overcome anxiety. Nurses should pay attention to anxiety and provide comprehensive nursing care. Nurses should not only focus on physical problems and ignore anxiety. This study implies on the process of nursing care and becomes foundation for anxiety management in health services. Nurses can use traditional music therapy to reduce anxiety because music is medicine to patients and it has no harmful side effects.

This study has a limitation that is the researcher does not have data about the use of sedation.

\section{Conclusion}

Gong waning music therapy can help decrease ACS patients' anxiety. This research supports the application of music therapy in overcoming anxiety. Nurses should not only focus on physical problems and ignore anxiety. It is hoped that nurses can use music 
Ode Irman: The Influence of Gong Waning Music Therapy toward Anxiety in Patients with Acute Coronary Syndrome

therapy as a non-pharmacological adjunct therapy to help reduce anxiety of ACS patients.

\section{References}

Abu Ruz, M.E., Lennie, T.A., \& Moser, D.K. (2010). Effects of-blockers and anxiety on complication rates after acute myocardial infarction. American Journal of Critical Care, 20(1), 67-74. https://doi.org/10.4037/ ajcc2010216

Abu Ruz, M.E., Lennie, T.A., Riegel, B., McKinley, S., Doering, L.V., \& Moser, D.K. (2010). Evidence that the brief symptom inventory can be used to measure anxiety quickly and reliably in patients hospitalized for acute myocardial infarction. The Journal of Cardiovascular Nursing, 25(2), 117-123. https://doi.org/10.1097/ jen.0b013e3181b56626

Aggelopoulou, Z., Fotos, N.V., Chatziefstratiou, A.A., Giakoumidakis, K., Elefsiniotis, I., \& Brokalaki, H. (2017). The level of anxiety, depression and quality of life among patients with heart failure in Greece. Applied Nursing Research, 34, 52-56. https:// doi.org/doi:10.1016/j.apnr.2017.01.003

Alamsah, M.S., Rahayuwati, L., \& Purba, C.I.H (2018) The effects of sundanese kacapi suling "ayun ambing" music therapy to the level of anxiety on chronic renal failure patient undergoing hemodialysis. Jurnal Keperawatan Padjadjaran, 6(1). https://doi. org/10.24198/jkp.v6i1.390

Benjamin, E.J., Virani, S.S., Callaway, C.W., Chamberlain, A.M., Chang, A.R., Cheng, S., ..., Deo, R. (2018). Heart disease and stroke statistics-2018, Update: A report from the American Heart Association. Circulation, 137(12), e67-e492. https://doi.org/10.1161/ cir.0000000000000558

Berbel, P., Moix, J., \& Quintana, S (2007). Music versus diazepam to reduce preoperative anxiety: A randomized controlled clinical trial. Revista Espanola de Anestesiologia y Reanimacion, 54(6), 355-358.
Boccara, G., Mazeraud, A., Cassagnol, D., Salluh, J.I.F., Guetin, S., \& Marret, E. (2018). A music therapy intervention (MUSIC-CARE) reduced the sedative dose during coronary angioplasty: A control-case comparison clinical study. Revista Brasileira de Terapia Intensiva, 30, S86-S86. https:// doi.org/10.47513/mmd.v13i4.811

Bradt, J., Dileo, C., Magill, L., \& Teague, A. (2016). Music interventions for improving psychological and physical outcomes in cancer patients. Cochrane Database Syst Rev., 15(8). https://doi.org/10.1002/14651858. cd006911.pub3

Bradley, Palmer, J., Lane, D., Mayo, D., Schluchter, M., \& Leeming, R. (2015). Effects of music therapy on anesthesia requirements and anxiety in women undergoing ambulatory breast surgery for cancer diagnosis and treatment: Arandomized controlled trial. Journal of Clinical Oncology, 33(28), 3162-3168. https://doi.org/10.1200/ jco.2014.59.6049

Bruscia, K. E. (2014). Defining Music Therapy, ePub version. Barcelona Publishers.

Busher, B., \& Daniel, . (2016). Madeleine Leininger and the transcultural theory of nursing. The Downtown Review, 2(1).

Celano, C.M., Millstein, R.A., Bedoya, C.A., Healy, B.C., Roest, A.M., \& Huffman, J.C. (2015). Association between anxiety and mortality in patients with coronary artery disease: A meta-analysis. American Heart Journal, 170(6), 1105-1115. https://doi. org/10.1016/j.ahj.2015.09.013

Chan, M.Y., Du, X., Eccleston, D., Ma, C., Mohanan, P.P., Ogita, M., ..., Jeong, Y.H. (2016). Acute coronary syndrome in the Asia-Pacific region. International Journal of Cardiology, 202, 861-869. https://doi. org/10.1016/j.ijcard.2015.04.073

Chlan, L.L., Weinert, C.R., Heiderscheit, A., Tracy, M.F., Skaar, D.J., Guttormson, J.L., \& Savik, K. (2013). Effects of patient-directed music intervention on anxiety and sedative 
Ode Irman: The Influence of Gong Waning Music Therapy toward Anxiety in Patients with Acute Coronary Syndrome

exposure in critically ill patients receiving mechanical ventilatory support. JAMA, 309(22), 2335-2344. https://doi.org/10.1001/ jama.2013.5670

Dahlan, S.M. (2013). Besar sampel dan cara pengambilan sampel. Salemba Medika.

Di Nasso, L., Nizzardo, A., Pace, R., Pierleoni, F., Pagavino, G., \& Giuliani, V. (2016). Influences of $432 \mathrm{hz}$ music on the perception of anxiety during endodontic treatment: a randomized controlled clinical trial. Journal of Endodontics, 42(9), 1338-1343. https:// doi.org/10.1016/j.joen.2016.05.015

Facai, L., Dehong, H., Nana, H., Yihuang, G., \& Yunchuan, W. (2017). Effect of music therapy derived from the five elements in Traditional Chinese Medicine on post-stroke depression. Journal of Traditional Chinese Medicine, 37(5), 675-680. https://doi. org/10.1016/s0254-6272(17)30322-9

Giger, J.N. (2016). Transcultural nursing-ebook: Assessment and intervention: Elsevier Health Sciences.

Good, M., \& Ahn, S. (2008). Korean and American music reduces pain in Korean women after gynecologic surgery. Pain Management Nursing, 9(3), 96-103. https:// doi.org/10.1016/j.pmn.2008.02.002

Hanser, S.B. (2014). Music therapy in cardiac health care. Cardiology in Review, 22(1), 37-42. https://doi.org/10.1097/ crd.0b013e318291c5fc

Hole, J., Hirsch, M., Ball, E., \& Meads, C. (2015). Music as an aid for postoperative recovery in adults: A systematic review and meta-analysis. The Lancet, 386(10004), 1659-1671. https://doi.org/10.1016/s01406736(15)60169-6

Julian L.J. (2011). Measures of anxiety: State-Trait Anxiety Inventory (STAI), Beck Anxiety Inventory (BAI), and Hospital Anxiety and Depression Scale-Anxiety (HADS-A). Arthritis Care \& Research, 63(11), S467-S472. https://doi.org/10.1002/ acr.20561
Leal, P.C., Goes, T.C., da Silva, L.C.F., \& Teixeira-Silva, F. (2017). Trait vs. state anxiety in different threatening situations. Trends in Psychiatry and Psychotherapy, 39(3), 147157. https://doi.org/10.1590/2237-60892016-0044

Lenze, E.J., Mantella, R.C., Shi, P., Goate, A.M., Nowotny, P., Butters, M.A., ..., Rollman, B.L. (2011). Elevated cortisol in older adults with generalized anxiety disorder is reduced by treatment: A placebo-controlled evaluation of escitalopram. American Association for Geriatric Psychiatry, 19(5), 482-490. https://doi.org/10.1097/ JGP.0b013e3181ec806c

Loomba, R.S., Arora, R., Shah, P.H., Chandrasekar, S., \& Molnar, J. (2012). Effects of music on systolic blood pressure, diastolic blood pressure, and heart rate: A meta-analysis. Indian Heart Journal, 64(3), 309-313. https://doi.org/10.1016/s00194832(12)60094-7

Maisyaroh, S.G., Rahayu, U., \& Rahayu, S.Y. (2015) Tingkat kecemasan pasien post operasi yang mengalami fraktur ekstremitas. (Anxiety levels of postoperative patients who have extremity fractures). Jurnal Keperawatan Padjadjaran 3(2). https://doi. org/10.24198/jkp.v3i2.103

Meneghetti, C.C., Guidolin, B.L., Zimmermann, P.R., \& Sfoggia, A. (2017). Screening for symptoms of anxiety and depression in patients admitted to a university hospital with acute coronary syndrome. Trends in Psychiatry and Psychotherapy, 39(1), 12-18. https://doi.org/10.1590/22376089-2016-0004

Miličić, D., Brajković, L., Maček, J.L., Andrić, A., Ardalić, Z., Buratović, T., \& Marčinko, D. (2016). Type a personality, stress, anxiety and health locus of control in patients with acute myocardial infarction. Psychiatria Danubina, 28(4), pp 409-414.

Ministry of Health of the Republic of Indonesia. (2018). Basic health research. Ministry of Health of the Republic of 
Ode Irman: The Influence of Gong Waning Music Therapy toward Anxiety in Patients with Acute Coronary Syndrome

Indonesia.

Musey, P.I., \& Kline, J.A. (2017). Emergency department cardiopulmonary evaluation of low-risk chest pain patients with selfreported stress and anxiety. Journal of Emergency Medicine, 52(3), 273-279. https://doi. org/10.1016/j.jemermed.2016.11.022

Nilsson, U. (2009). The effect of music intervention in stress response to cardiac surgery in a randomized clinical trial. Heart \& Lung: The Journal of Acute and Critical Care, 38(3), 201-207. https://doi. org/10.1016/j.hrtlng.2008.07.008

Nuraeni, A., Mirwanti, R., Anna, A., Prawesti, A., \& Emaliyawati, E. (2016). Faktor yang memengaruhi kualitas hidup pasien dengan penyakit jantung koroner. (Factors that affect the quality of life of patients with coronary heart disease). Jurnal Keperawatan Padjadjaran, 4(2). https://doi.org/10.24198/ jkp.v4i2.231

Ohira, T., \& Iso, H. (2013). Cardiovascular disease epidemiology in Asia: An overview. Circ J., 77(7), 1646-52. https://doi. org/10.1253/circj.CJ-13-0702

Okrainec, K., Banerjee, D.K., \& Eisenberg, M.J. (2004). Coronary artery disease in the developing world. American Heart Journal, 148(1), 7-15. https://doi.org/10.1016/j. ahj.2003.11.027

Parker, G.B., Owen, C.A., Brotchie, H.L., \& Hyett, M.P. (2010). The impact of differing anxiety disorders on outcome following an acute coronary syndrome: time to start worrying?. Depression and Anxiety, 27(3), 302-309. https://doi.org/10.1002/da.20602

Piironen, M., Ukkola, O., Huikuri, H., Havulinna, A.S., Koukkunen, H., Mustonen, J., ..., Salomaa, V. (2016). Trends in long-term prognosis after acute coronary syndrome. European Journal of Preventive Cardiology, 24(3), 274-280. https://doi. org/10.1177/2047487316679522

Rahman, A., Santoso, B., \& Sudirman. (2017). Effect of hariring kabayan instrumental music therapy on pain and anxiety level in patients with acute myocardial infarction. Belitung Nursing Journal, 4(1), 89-97. https://doi. org/10.33546/bnj.340

Roest, A.M., Martens, E.J., Denollet, J., \& de Jonge, P. (2010). Prognostic association of anxiety post myocardial infarction with mortality and new cardiac events: A meta-analysis. Psychosomatic Medicine, 72, 563-569. https://doi.org/10.1097/ PSY.0b013e3181dbff97

Roest, A.M., Heideveld, A., Martens, E.J., de Jonge, P., \& Denollet, J. (2014). Symptom dimensions of anxiety following myocardial infarction: Associations with depressive symptoms and prognosis. Health Psychology, 33(12), 1468-1476. https://doi.org/10.1037/ a0034806

Sanchis-Gomar, F., Perez-Quilis, C., Leischik, R., \& Lucia, A. (2016). Epidemiology of coronary heart disease and acute coronary syndrome. Annals of translational medicine, 4(13), 256. https://doi.org/10.21037/ atm.2016.06.33

Sastroasmoro, S. (2014). Dasar-dasar metodologi penelitian klinis (Edisi ke5). (Fundamentals of clinical research methodology (5th Edition)). CV. Sagung Seto.

Spielberger, C.D. (2010). Statetrait anxiety inventory. The corsini encyclopedia of psychology. https://doi. org/10.1002/9780470479216.corpsy0943

Supnet, C., Crow, A., Stutzman, S., \& Olson, D. (2016). Music as medicine: The therapeutic potential of music for acute stroke patients. Critical Care Nurse, 36(2), e1-e7. https:// doi.org/10.4037/cen2016413

Stern, C. (2013). Music interventions for preoperative anxiety. International Journal of Evidence-Based Healthcare, 11(3), 208-209. https://doi.org/10.1111/1744-1609.12031

Tao, W.-W., Jiang, H., Tao, X.-M., Jiang, P., Sha, L.-Y., \& Sun, X.-C. (2016). Effects of acupuncture, tuina, tai chi, qigong, and 
Ode Irman: The Influence of Gong Waning Music Therapy toward Anxiety in Patients with Acute Coronary Syndrome

traditional chinese medicine five-element music therapy on symptom management and quality of life for cancer patients: A meta-analysis. Journal of Pain and Symptom Management, 51(4), 728-747. https://doi. org/10.1016/j.jpainsymman.2015.11.027

Thompson, W.F. (2009). Music, thought, and feeling: Understanding the psychology of music. Oxford University Press.

Toker, E., \& Kömürcü, N. (2017). Effect of Turkish classical music on prenatal anxiety and satisfaction: A randomized controlled trial in pregnant women with preeclampsia. Complementary Therapies in Medicine, 30, 1-9. https://doi.org/10.1016/j. ctim.2016.11.005

Townsend, N., Wilson, L., Bhatnagar, P., Wickramasinghe, K., Rayner, M., \& Nichols, M. (2016). Cardiovascular disease in Europe: Epidemiological update 2016. European Heart Journal, 37(42), 3232-3245. https:// doi.org/10.1093/eurheartj/ehw334

Trappe, H. (2010) The effects of music on the cardiovascular system and cardiovascular health. Heart, 96, 1868-1871. http://dx.doi. org/10.1136/hrt.2010.209858
Wan-Nor-Asyikeen, W.A., Siti-Azrin, A.H., Sulong, Z.R., \& Hashairi, F.M. (2017). Associated Factors of Anxiety among Acute Coronary Syndrome Patients in Kelantan and Terengganu. Iran J Health Sci., 5(4), 1-9. https://doi.org/10.29252/jhs.5.4.1

Yeo, J.K., Cho, D.Y., Oh, M.M., Park, S.S., \& Park, M.G. (2013). Listening to music during cystoscopy decreases anxiety, pain, and dissatisfaction in patients: A pilot randomized controlled trial. Journal of Endourology, 27(4), 459-462. https://doi.org/10.1089/ end.2012.0222

Yusli, U.D., \& Rachma, N. (2019). Pengaruh pemberian terapi musik gamelan jawa terhadap tingkat kecemasan lansia. (The effect of giving Javanese gamelan music therapy on the level of anxiety in the elderly). Jurnal Perawat Indonesia, 3(1), 72-78. https://doi.org/10.32584/jpi.v3i1.290

Zhou, K.N., Li, X.M., Yan, H., Dang, S.N., \& Wang, D.L. Effects of music therapy on depression and duration of hospital stay of breast cancer patients after radical mastectomy. Chinese Medical Journal, 124(15), 2321-2327. https://doi.org/10.3760/ cma.j.issn.0366-6999.2011.15.014 